\title{
Ultrastructural studies of plasmodesmatal and vascular translocation of tobacco rattle virus (TRV) in tobacco and potato
}

\author{
Grażyna Garbaczewska • Katarzyna Otulak • \\ Marcin Chouda $\cdot$ Mirosława Chrzanowska
}

Received: 21 July 2011/Revised: 8 February 2012/Accepted: 9 February 2012/Published online: 23 February 2012

(C) The Author(s) 2012. This article is published with open access at Springerlink.com

\begin{abstract}
The studies focus on an ultrastructural analysis of the phenomenon of intercellular and systemic (vascular) transport of tobacco rattle virus (TRV) in tissues of the infected plants. TRV is a dangerous pathogen of cultivated and ornamental plants due to its wide range of plant hosts and continuous transmission by vectors-ectoparasitic nematodes. Two weeks after infection with the PSG strain of TRV, tobacco plants of the Samsun variety and potato plants of the Glada variety responded with spot surface necroses on inoculated leaf blades. Four weeks after the infection a typical systemic response was observed on tobacco and potato leaves, necroses on stems and lesions referred to as corky ringspot. Ultrastructural analysis revealed the presence of two types of TRV virions: capsidated and non-capsidated forms in tobacco and potato tissues. In the protoplast area, viral particles either occurred in a dispersed form or they formed organised inclusions of virions. We demonstrated for the first time the presence of non-capsidated-type TRV in the vicinity of and inside plasmodesmata. Capsidated particles of TRV were observed in intercellular spaces of the tissues of aboveground and underground organs. Expanded apoplast area was noted at the cell wall, with numerous dispersed non-
\end{abstract}

Communicated by M. Stobiecki.

G. Garbaczewska $\cdot$ K. Otulak $(\bowtie) \cdot$ M. Chouda

Department of Botany, Faculty of Agriculture and Biology,

Warsaw University of Life Sciences-SGGW,

Nowoursynowska 159, 02-776 Warsaw, Poland

e-mail: katarzyna_otulak@sggw.pl

M. Chrzanowska

Research Division at Młochów,

Plant Breeding and Acclimatization Institute,

National Research Institute, Platanowa 9,

05-831 Młochów, Poland capsidated-type TRV particles. These phenomena suggest active intercellular transport. Our ultrastructure studies showed for the first time that xylem can be a possible route of TRV systemic transport. We demonstrated that both capsidated and non-capsidated virions, of varied length, participate in long-distance transport. TRV virions were more often documented in xylem (tracheary elements and parenchyma) than in phloem. Non-capsidated TRV particles were observed inside tracheary elements in a dispersed form and in regular arrangements in potato and tobacco xylem. The presence of TRV virions inside the bordered pits was demonstrated in aboveground organs and in the root of the tested plants. We documented that both forms of TRV virions can be transported systemically via tracheary elements of xylem.

Keywords Intercellular movement - Plasmodesmata . Tobravirus · Vascular transport

\section{Introduction}

Tobacco rattle virus (TRV) is a wide-spread pathogen in the plant world. Over 400 plant species from monocotyledon and dicotyledon classes can serve as hosts for the virus. The most common hosts are cultivated plants such as potato, sugar beet, tobacco and tomato (Allen 1963; Huth and Lesemann 1984). TRV belongs to the Tobravirus genus. It has a bipartite genome and it is made of two single strands of positive polarity (+)ssRNA. The genetic material undergoes separate encapsidation into simple, rodshaped, helical capsids, with identical diameters of $22.5 \mathrm{~nm}$. The virions of TRV vary in terms of length: longer particles (L) range from 180 to $197 \mathrm{~nm}$ and shorter particles (S) from 55 to $114 \mathrm{~nm}$. Both types of virions have 
Fig. 1 Symptoms of TRV PSG infection. a Leaf blade of healthy tobacco cv. Samsun, plant inoculated with phosphate buffer; $\mathbf{b}$ leaves of tobacco $\mathrm{cv}$. Samsun 3 weeks after TRV PSG infection. Necrotic and chlorotic lesions in the form of rings or mottle (arrows); c surface necroses of tobacco stems 3 weeks after TRV infection; d arch-shaped, irregularly distributed necroses covering all the tuber tissues of potato $\mathrm{cv}$. Glada. Corky ringspot

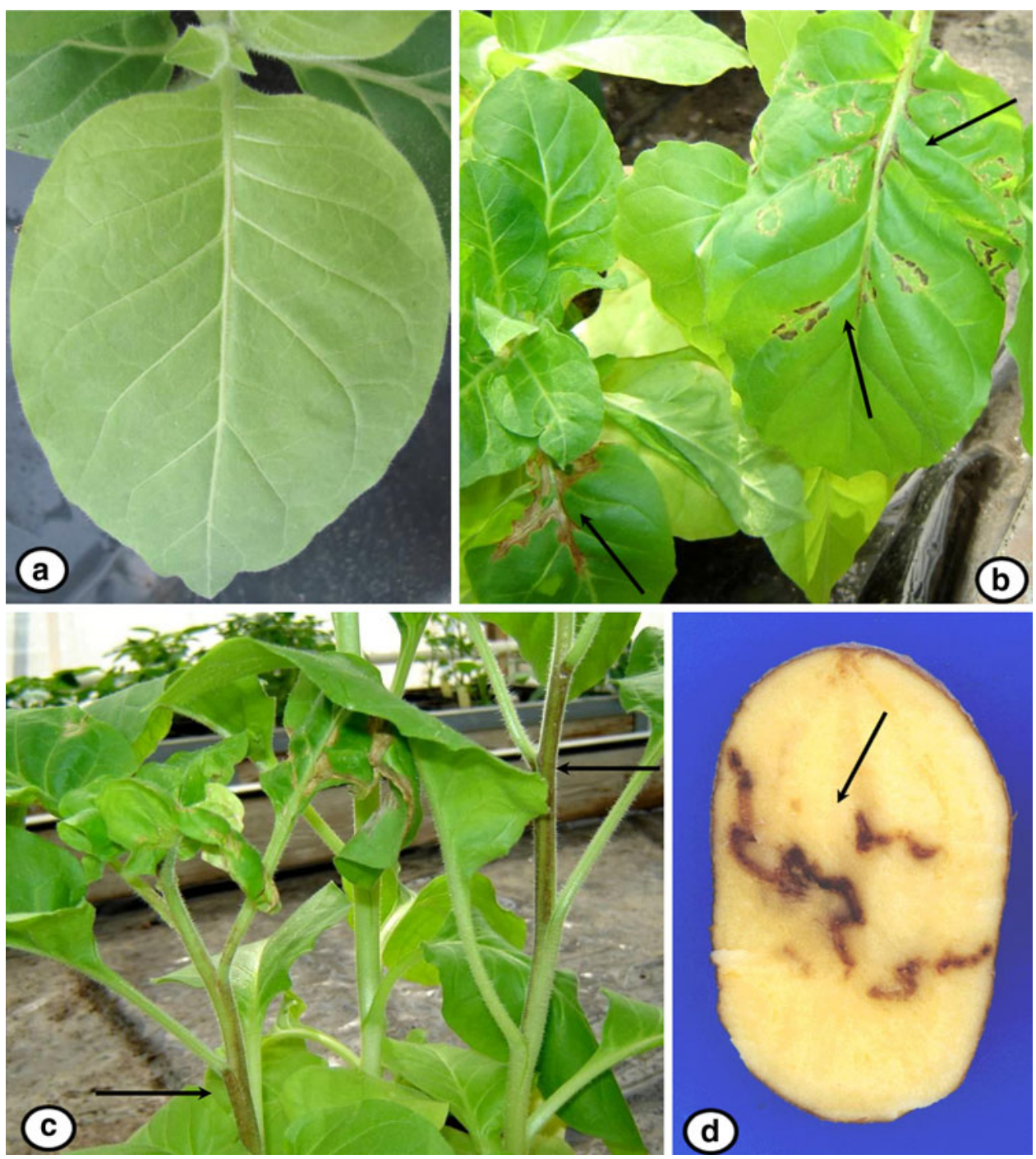

5\% RNA and $95 \%$ of protein. The virions of these two kinds fulfil different functions in the processes of viral infection and multiplication in a plant. The longer particle, containing RNA1, induces infection, whereas the shorter one, containing RNA2, is responsible for creating a coat protein (CP) for both strands (Bergh et al. 1985). If the plant is infected only by L particles, only RNA of these particles multiplies (Frost et al. 1967). Such TRV form was referred to as non-multiplying (NM). It is sensitive to ribonucleases and it is easily degradable in plant sap. Complete virions known as capsidated forms appear in the plant, when both types of TRV virions and/or their RNA are present (Harrison and Robinson 1978; MacFarlane 1999, 2010).

RNA1 has four open reading frames (ORF) which encode the proteins that participate in virus replication and transmission by vectors-nematodes, and it is believed that they also take part in cell-to-cell movement of the virus
(Hamilton and Baulcombe 1989). RNA2 encodes coat protein and plays a part in the transmission by nematodes (protein 16 K) (Ploeg et al. 1993; MacFarlane and Brown 1995). The TRV strains have been classified and those isolated from potatoes that are relatively well described include: PRN (Scotland), strains from Oregon (Lister and Bracker 1969), and PSG-a strain isolated in the Netherlands and described for the first time by Cornelissen et al. (1986).

Current studies on TRV focus on strains and their recombinants that are transmitted mostly by nematodes of the Trichodorus and Paratrichodorus species. In our studies we used the method of mechanical inoculationone of the basic possibilities of infection in field, greenhouse or laboratory conditions. The objective of these studies was to present the phenomenon of intercellular and vascular translocation of the PSG strain of TRV in potato and tobacco tissues at the ultrastructural level. 


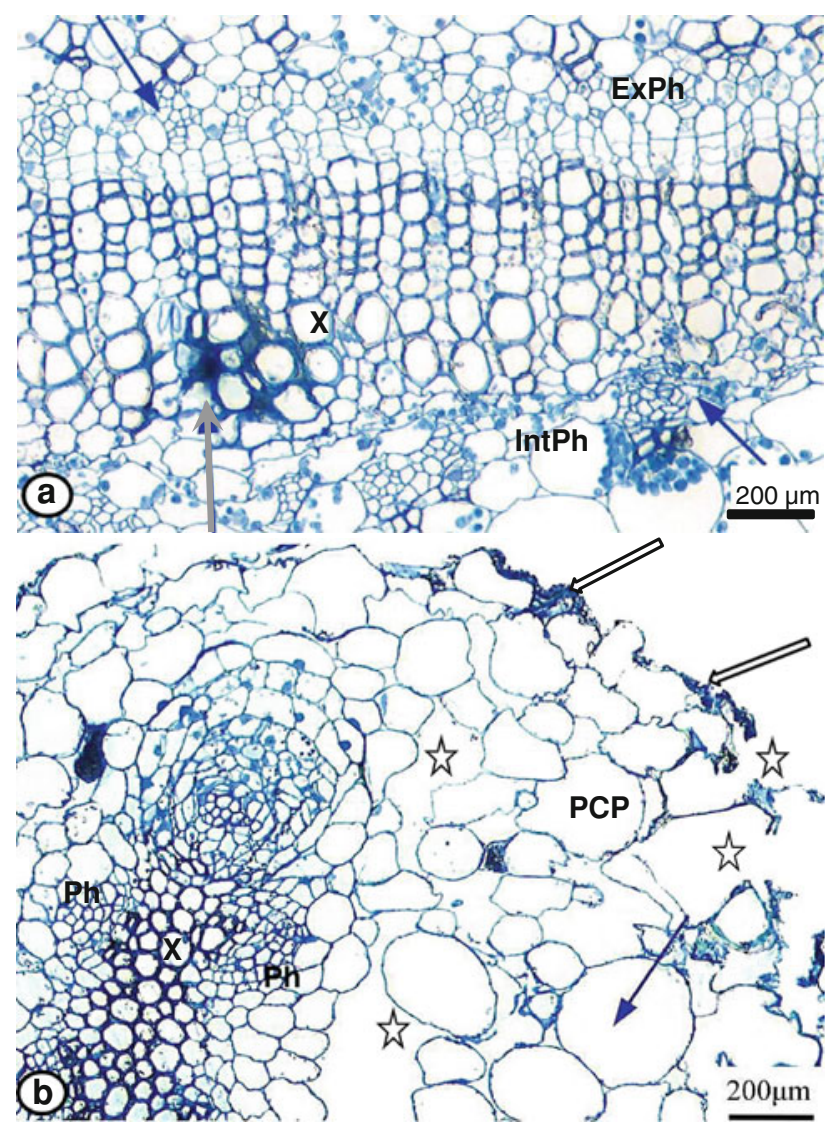

Fig. 2 Anatomical changes caused by TRV PSG infection. a Cross section of a fragment of vascular bundles in tobacco stem 3 weeks after TRV infection. Necroses of xylem (X) and internal phloem (IntPh) have been marked with arrows (X grey arrow; $\mathrm{Ph}$ dark). External phloem $(\mathrm{ExPh})$ and internal phloem have been marked with white arrows; $\mathbf{b}$ root cross section for potato cv. Glada 3 weeks after TRV infection. Rhizodermis necrosis ( $\mathrm{R}$ white arrows) and hypertrophy of primary cortex parenchyma (PCP dark arrows) cells. Spots where rhizodermis and primary cortex cell walls were damaged have been indicated with an asterisk

\section{Materials and methods}

Plants material

Plants of Solanum tuberosum cv. Glada and Nicotiana tabacum cv. Samsun were grown in a growth chamber, at a temperature of $18^{\circ} \mathrm{C}$ and a 16-h light cycle with the intensity of $400 \mu \mathrm{mol} \mathrm{m}{ }^{-2} \mathrm{~s}^{-1}$ PAR. Plants at four leaf stage were infected with the PSG strain of TRV. Plants were mechanically inoculated with TRV suspension using carborundum, in a $0.1 \mathrm{M}$ phosphate buffer ( $\mathrm{pH}$ 7.4). The virus isolate was received from Institute of Phytopathological Research, Wageningen (The Netherlands). Control plant material was inoculated only with phosphate buffer. The plants of tobacco cv. Samsun used as a material for infection, and the infected plants of potato were tested

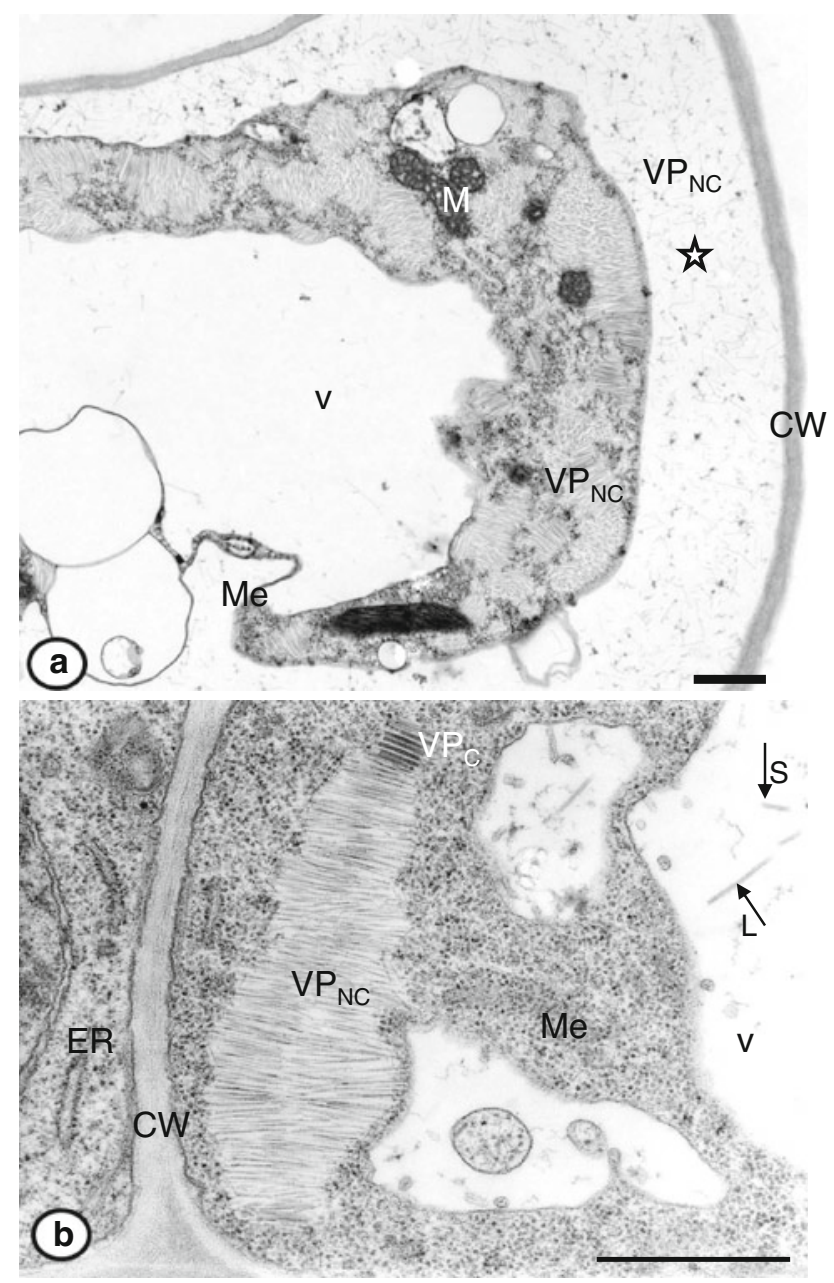

Fig. 3 Two types of TRV virions in tobacco mesophyll cells. a Inclusions of non-capsidated TRV particles $\left(\mathrm{VP}_{\mathrm{NC}}\right)$ in tobacco mesophyll (Me) cell. Protoplast at a considerable distance from cell wall $(\mathrm{CW})$. In the space of cell wall apoplast, dispersed noncapsidated TRV particles $\left(\mathrm{VP}_{\mathrm{NC}}\right)$ have been marked with an asterisk. $M$ mitochondrion, $V$ vacuole, $\operatorname{Bar} 500 \mathrm{~nm}$; b capsidated $\left(\mathrm{VP}_{\mathrm{C}}\right)$ and non-capsidated $\left(\mathrm{VP}_{\mathrm{NC}}\right) \mathrm{TRV}$ particles in an organised form in tobacco mesophyll $(\mathrm{Me})$ cell. Inside vacuole $(\mathrm{V})$ visible non-capsidated type TRV particles (L and $\mathrm{S}$ form, indicated by arrows). $C W$ cell wall, $E R$ endoplasmic reticulum, Bar $500 \mathrm{~nm}$

using the DAS-ELISA procedure at IHAR Młochów (according to Clark and Adams 1977, immunoglobulins received from D. Z. Maat, Wageningen, The Netherlands). The plant organs were collected (depending on symptoms) 2, 3 and 4 weeks after TRV infection. The investigations were repeated three times.

Analysis in transmission electron microscope (TEM)

The material was fixed in $2 \%(\mathrm{w} / \mathrm{v})$ paraformaldehyde and $2 \%(\mathrm{v} / \mathrm{v})$ glutaraldehyde in a $0.05 \mathrm{M}$ cacodylate buffer $(\mathrm{pH}$ 


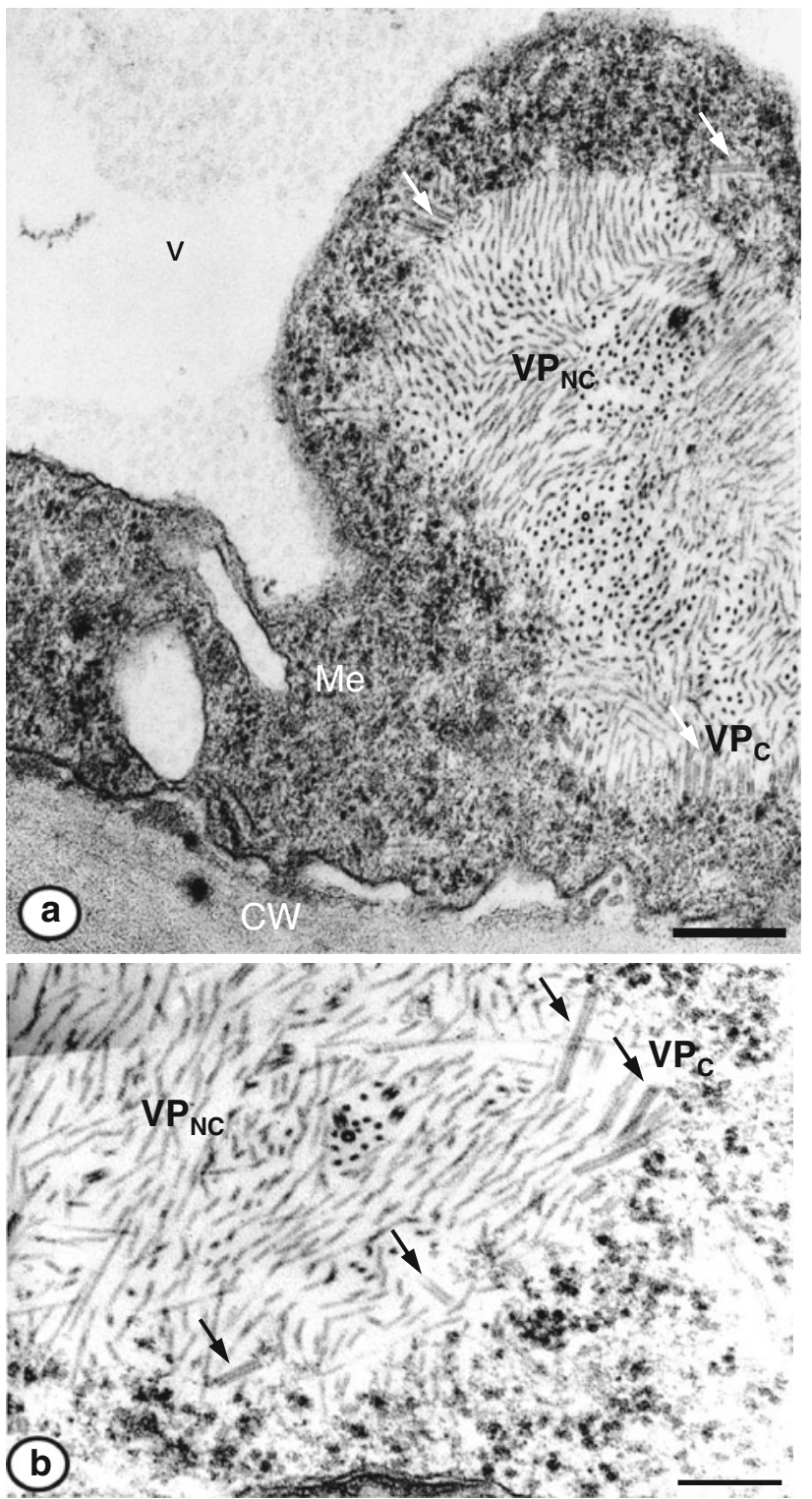

Fig. 4 Two types of TRV virions in potato mesophyll cells. a Inclusion of TRV particles in mesophyll (Me) cell cytoplasm of potato cv. Glada. Current capsidated (arrows) and non-capsidated particles. $C W$ cell wall, $V$ vacuole, $B a r 150 \mathrm{~nm}$; b Enlarged fragment a, $\operatorname{Bar} 0.1 \mu \mathrm{m}$

7.2-7.4) (Karnovsky 1965) $2 \mathrm{~h}$ at room temperature. Next, the samples were contrasted and fixed in $2 \%(\mathrm{w} / \mathrm{v}) \mathrm{OsO}_{4}$ in cacodylate buffer for $2 \mathrm{~h}$ at $4^{\circ} \mathrm{C}$. The material was rinsed with sodium cacodylate and then dehydrated in a series of increasingly strong water solutions of ethanol. The material was gradually saturated with resin Epon 812 (Fluka) and polymerized for $24 \mathrm{~h}$ at $60^{\circ} \mathrm{C}$. The ultrathin sections on copper grids were stained with uranyl acetate and lead citrate.
Observations were made using a Morgagni 268D (FEI) transmission electron microscope. Photographic documentation was prepared with a Morada (SIS) digital camera and the iTEM (SIS) computer programme.

\section{Results}

Symptoms and anatomical changes

Two weeks after the infection with the PSG TRV, tobacco plants of the Samsun variety and potato plants of the Glada variety responded with spot surface necroses on inoculated leaf blades. Three weeks after the infection, typical deformations appeared on tobacco leaves (Fig. 1b). Necrotic and chlorotic lesions took the form of rings or mottle, sometimes, a mosaic on upper leaves. Four weeks after the TRV infection, the systemic response not only included leaf blades and leaf petioles but also surface necroses of stems (Fig. 1c). Infection of potato cv. Glada covered also underground organs and corky ringspot was observed. Arch-shaped, irregularly distributed necroses covered all the tuber tissues (Fig. 1d). All these symptoms inhibited the growth and development of hosts in comparison with control plants, where no necrotic changes were observed (Fig. 1a).

Three weeks after PSG TRV infection, anatomic lesions in tobacco and potato leaf blades mostly affected the cells of epidermis and palisade parenchyma. Also, 4 weeks after the TRV infection in leaf petioles and in the stem, necroses and deformations of cell groups affected phloem (Fig. 2a). In tobacco and potato root tissues, necroses and deformations of rhizodermis were observed. They were accompanied by hypertrophy of the primary cortex parenchyma (Fig. 2b). Necrotic lesions of this organ were usually limited to epidermis cells of root and primary cortex; no necroses of vascular tissues were detected at the anatomic level.

Intercellular TRV translocation

Ultrastructural analysis revealed the presence of two types of TRV virions: capsidated and non-capsidated forms in tobacco (Fig. 3b) and potato mesophyll (Fig. 4a, b). Noncapsidated TRV virions were observed in the area of protoplast in a dispersed (Figs. 3a, 4a) or organised form (Fig. 3b). In the mesophyll apoplast, non-capsidated type TRV virions (Fig. 3a) were dispersed. TRV particles were observed in the direct vicinity of or in contact with plasmodesmata, in the cells of both aboveground and underground organs. TRV particles in contact with plasmodesmata occurred most commonly in mesophyll tissues 

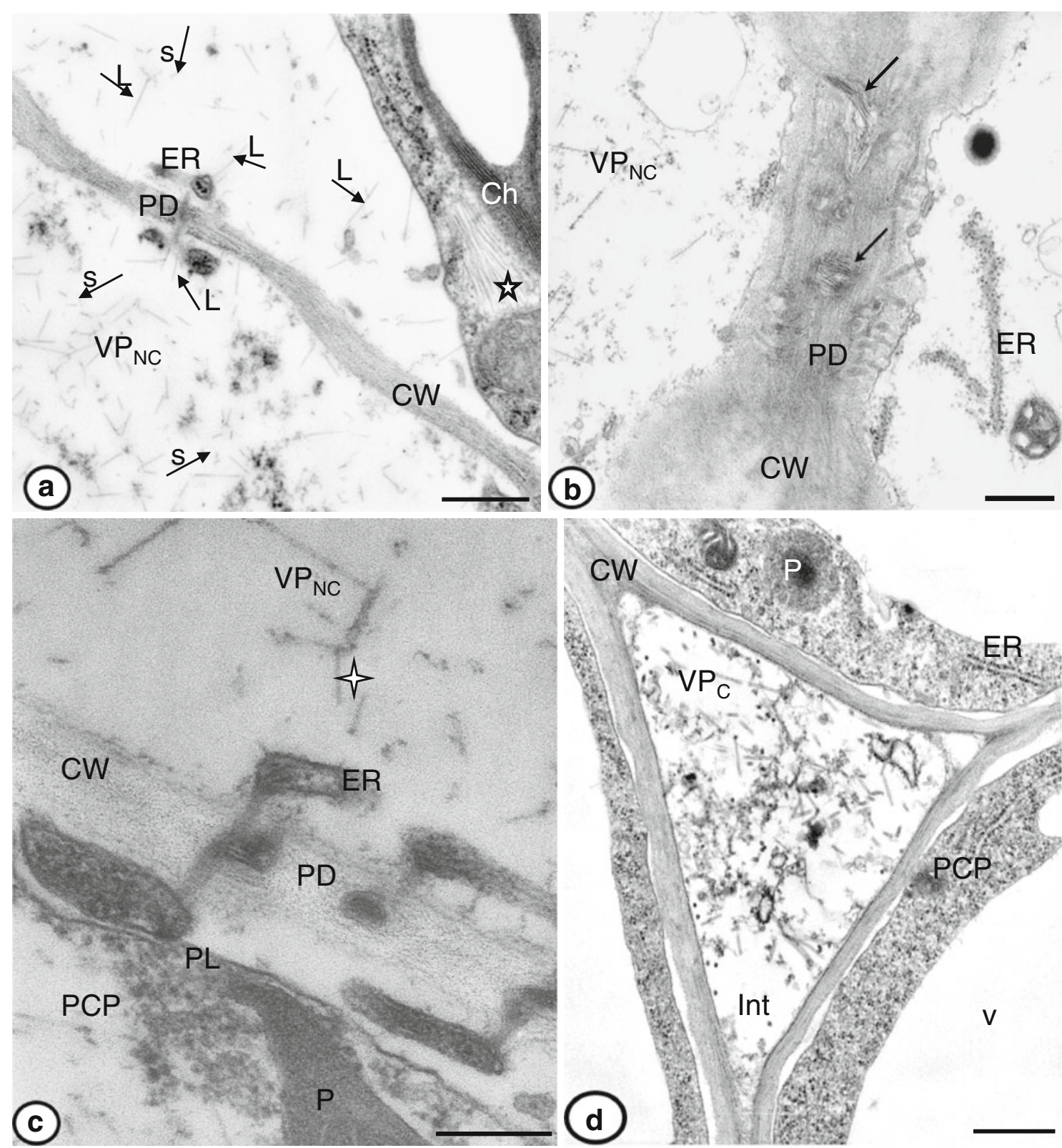

Fig. 5 Symplastic and/or apoplastic translocation of TRV virions. a Plasmodesmatal desmotubules (PD) attached to the ER cisternae of the neighbouring tobacco mesophyll cells. Protoplast at a considerable distance from cell wall $(\mathrm{CW})$. Non-capsidated $\mathrm{L}$ and $\mathrm{S}$ TRV particles (marked with arrows, $\mathrm{VP}_{\mathrm{NC}}$ ) in the vicinity of plasmodesmata and in the protoplast (asterisk). Ch chloroplast, Bar $500 \mathrm{~nm}$; b non-capsidated TRV particles $\left(\mathrm{VP}_{\mathrm{NC}}\right)$ inside (arrows) and in the vicinity of branched plasmodesmata (PD) in tuber storage parenchyma of potato cv. Glada. $C W$ cell wall, ER endoplasmic reticulum,
Bar $200 \mathrm{~nm}$; c expanded cell wall apoplast of neighbouring cells of primary cortex parenchyma (PCP) in stem of potato cv. Glada. Granular contents of ER cisternae released within the apoplast. Loosened cell wall $(\mathrm{CW})$ structure. Visible non-capsidated TRV particles $\left(\mathrm{VP}_{\mathrm{NC}}\right)$ in $\mathrm{L}$ and $\mathrm{S}$ forms (asterisks). $P$ plastid, $P D$ plasmodesmata, $P L$ plasmalemma, Bar $100 \mathrm{~nm}$; d capsidated particles $\mathrm{VP}_{\mathrm{C}}$ in $\mathrm{L}$ and $\mathrm{S}$ form in intercellular spaces (Int) of tobacco root primary cortex parenchyma (PCP). $C W$ cell wall, $E R$ endoplasmic reticulum, $P$ plastid, $V$ vacuole, Bar $500 \mathrm{~nm}$
(Fig. 5a, b), mainly in the non-capsidated form. Plasmodesmatal desmotubules very often combined with endoplasmic reticulum cisternae, especially in the area where cell protoplast was away from the cell wall (Fig. 5a, c). The area of the cell wall apoplast of neighbouring cells expanded and the granular contents of the ER cisternae was released to the apoplast. Non-capsidated virions of TRV were observed in the vicinity of and inside branched plasmodesmata and in underground organs, e.g. in storage parenchyma of potato cv. Glada (Fig. 5b). In cells that 


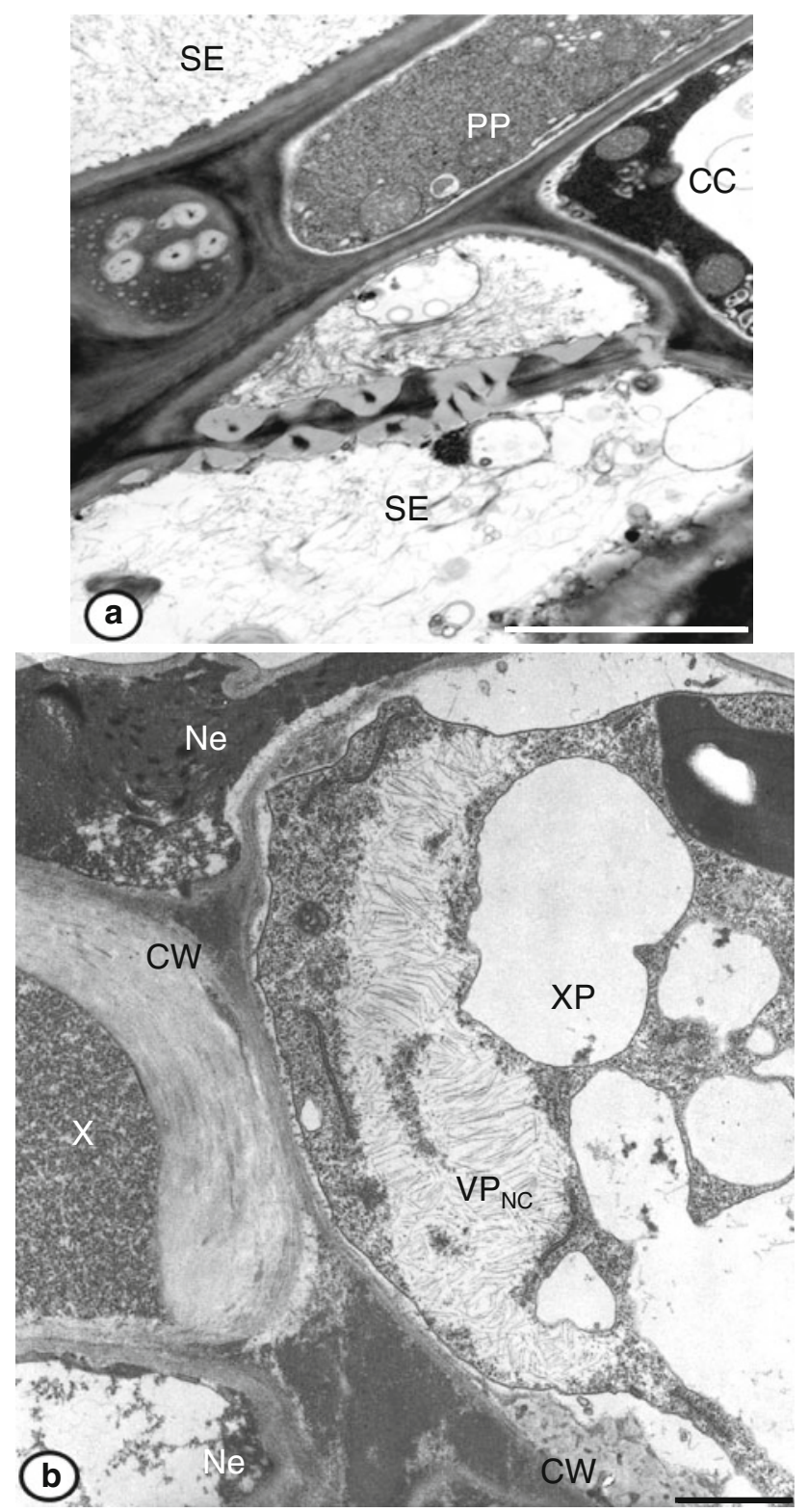

Fig. 6 Necrosis in vascular tissues. a Fragment of tobacco leaf vascular bundle. Necrosis of phloem sieve elements (SE), phloem parenchyma (PP) or companion cells (CC). Bar $2.5 \mu \mathrm{m}$; b necrosis of xylem parenchyma (XP) from potato stem, deformation of cell walls $(\mathrm{CW})$. Inclusions of non-capsidated TRV particles $\left(\mathrm{VP}_{\mathrm{NC}}\right)$ in xylem parenchyma cells. Tracheary elements $(\mathrm{X})$ include an osmophilic substance. Ne necrosis, Bar $500 \mathrm{~nm}$

contained numerous non-capsidated TRV virions, changes in cell wall structure were observed. Structural components of the wall were characterised by lower electron density and less densely arranged fibrils (Fig. 5b, c). In areas where many TRV particles occurred in the cell wall apoplast, the cell wall was much thinner, sometimes undergoing deformation (Fig. 5a). No cell-to-cell transport of capsidated forms was observed in the studied material.
Capsidated forms were noted in intercellular spaces of parenchyma in aboveground and underground organs (e.g. tobacco root primary cortex parenchyma, Fig. 5d), that the completed form of TRV virions are also transport at a short-distance.

\section{Systemic movement}

Ultrastructural analysis of conductive tissues in TRVinfected plants showed that in the case of aboveground parts of tobacco plants it was usually phloem cells, phloem parenchyma cells or companion cells that were necrotised (Fig. 6a). In the case of aboveground parts of potatoes, necroses usually appeared in the xylem area (Fig. 6b). Necrotised cells of xylem parenchyma had highly deformed cell walls. In living cells there were considerable inclusions of non-capsidated TRV virions. Tracheary elements often included an osmophilic substance. Within phloem free from necroses, both types of TRV particles were observed. In sieve elements regular non-capsidated particles were observed (Fig. 7a, b), which is evidence for systemic transport of these particles. Capsidated TRV virions occurred in the companion cells that are near plasmodesma which connected them with the sieve element (Fig. 7c). These observations confirm the fact that it is phloem that is the main systemic transport route for assimilates, and also for pathogens. Apart from companion cells, no multiplying TRV particles were observed directly inside the sieve elements (SE).

Ultrastructure studies showed that xylem can also be a route of TRV systemic transport. In xylem parenchyma cells, both in tobacco and potatoes, capsidated and noncapsidated TRV virions were observed (Fig. 8a-c). These particles were dispersed in cytoplasm (Fig. 8a) or they occurred as organised inclusions (Fig. 8b, c). The noncapsidated TRV virions were observed inside tracheary elements in a dispersed form (Fig. 9a) and in regular arrangements (Fig. 10a, b), both in potato and in tobacco xylem. TRV virions were observed also in bordered pits in aboveground organs and in the root (Fig. 9a, b). Both forms of TRV virions can be transported systemically via tracheary elements of xylem. The occurrence of completed viral particles at cross section and longitudinal section in the lumen of bordered pits suggests that the long-distance transport takes place in vessel segments and locally between neighbouring tracheary elements (Fig. 9b).

\section{Discussion}

Mechanical infection with the PSG strain of TRV led to a systemic response of susceptible potato and tobacco plants. 


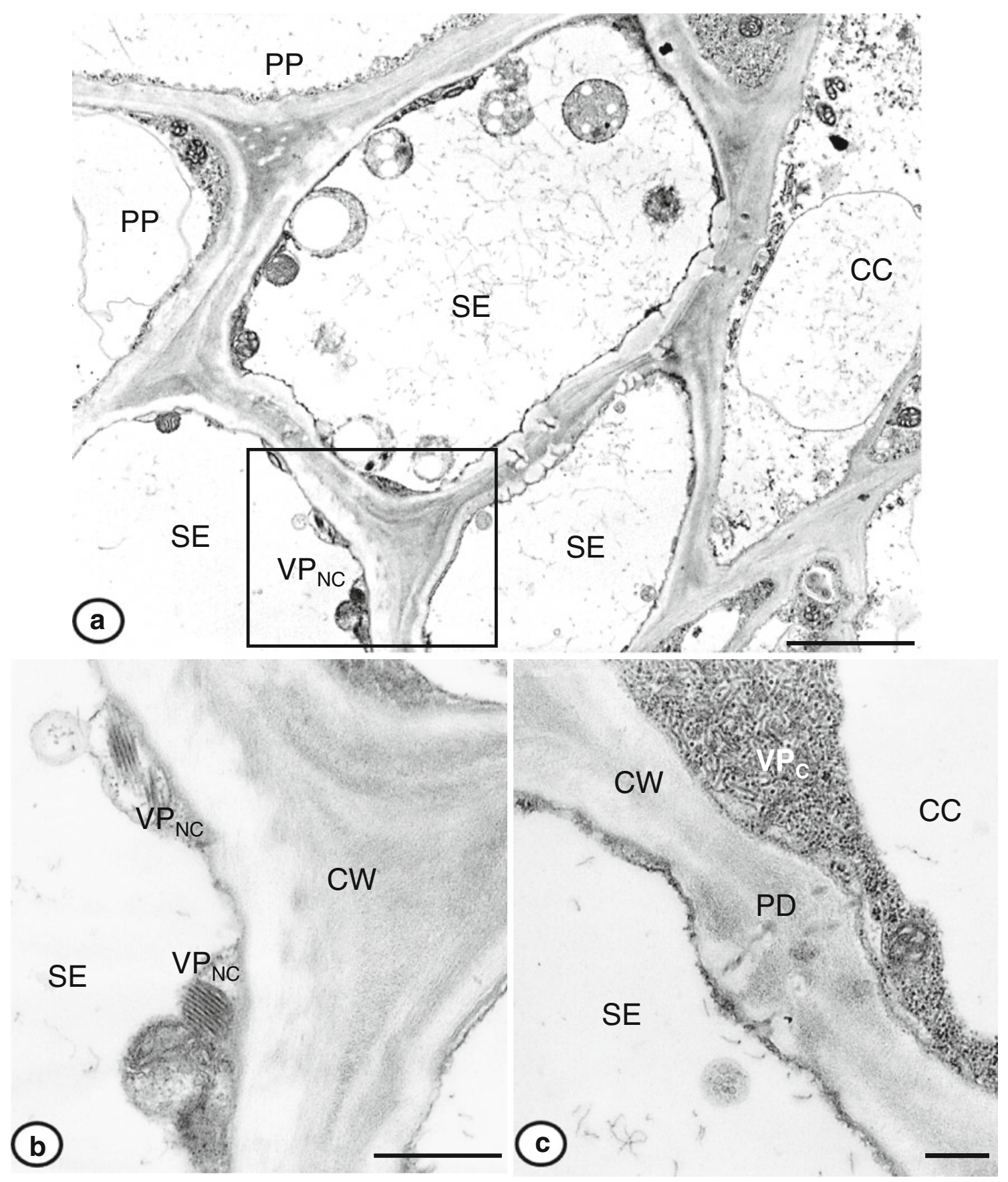

Fig. 7 TRV virions in phloem cells. a Fragment of phloem of tobacco root vascular bundle. TRV particles $\mathrm{VP}_{\mathrm{NC}}$ (marked area) in the sieve element $(S E)$. $C C$ companion cells, $P P$ phloem parenchyma, Bar $3 \mu \mathrm{m}$; b enlarged marked fragment from a. $C W$ cell wall,

Symptoms developed in inoculated and non-inoculated leaves, in stems and potato tubers. Anatomic lesions occurred in all plant organs of the hosts. Apoplast/intercellular transport was observed in tissues of the aboveground and underground parts of plants. The Tobravirus $29 \mathrm{kDa}$ MP is most closely related to the Tobamoviruses
$S E$ sieve element, $V P_{N C}$ non-capsidated virus particles, $B a r 500 \mathrm{~nm}$; c capsidated TRV particles $\left(\mathrm{VP}_{\mathrm{C}}\right)$ in companion cells $(\mathrm{CC})$ that are situated near plasmodesma (PD) and that communicate it with the sieve element (SE). $C W$ cell wall, Bar $200 \mathrm{~nm}$

and share a common mechanism for cell-to-cell movement (Ziegler-Graff et al. 1991; Carrington et al. 1996). There has been very little research exploring the mechanism for Tobraviruses movement. However, because of the close relationships between Tobraviruses and Tobamoviruses, a model describing cell-to-cell movement has also been used 
Fig. 8 TRV virions in xylem parenchyma cells. a Tobacco leaf xylem parenchyma (XP). Dispersed capsidated (indicated by arrows, $\mathrm{VP}_{\mathrm{C}}$ ) and noncapsidated TRV particles $\left(\mathrm{VP}_{\mathrm{NC}}\right)$ in $\mathrm{L}$ and $\mathrm{S}$ forms. Particles in contact with ER and plasmodesma (PD) between xylem parenchyma cells. $X$ xylem tracheary element, Bar $2 \mu \mathrm{m}$; b non-capsidated TRV particles $\mathrm{VP}_{\mathrm{NC}}$ in the form of organised inclusions (indicated by arrow) in tobacco stem xylem parenchyma (XP) cell. $X$ xylem tracheary element, Bar $500 \mathrm{~nm}$; c organised inclusions of capsidated TRV particles $\left(\mathrm{VP}_{\mathrm{C}}\right)$ in the stem xylem parenchyma (XP) of potato $\mathrm{cv}$. Glada. $C W$ cell wall, Bar $400 \mathrm{~nm}$

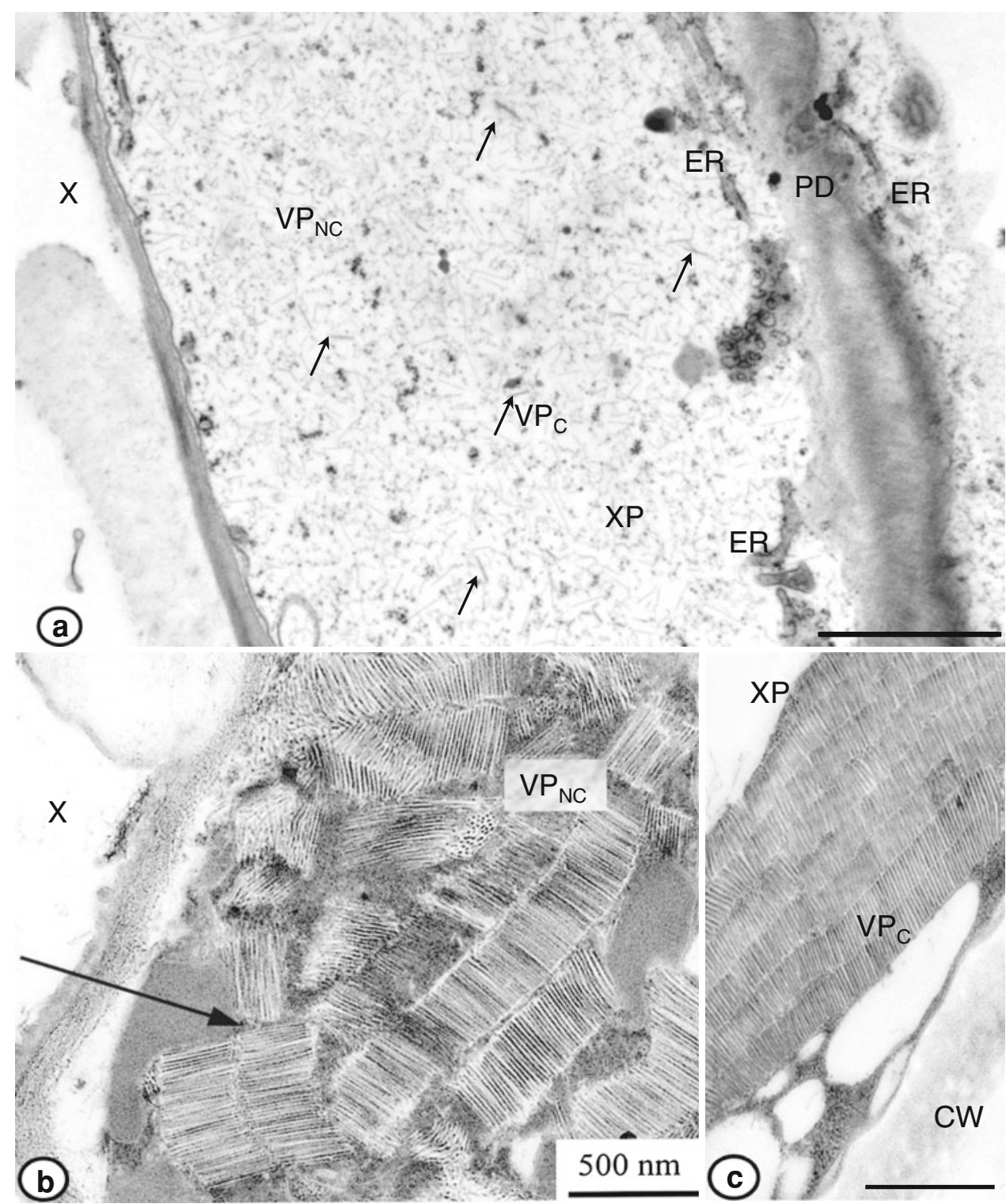

to describe the mechanism for Tobravirus local transport. In this model, viruses move from cell to cell in the absence of CP. Viral movement proteins cooperatively bind viral nucleic acid forming a ribonucleoprotein complex that is transported through plasmodesma into adjacent cells.

Holeva and MacFarlane (2006) showed that RNA2encoded protein $2 b$ is essential for TRV transmission by nematodes, but it can be also responsible for physical interaction with coat protein. The PSG strain of TRV has RNA2, so it encodes protein $2 b$ and $C P$ and leads to the formation of completed and non-capsidated particles in tissues ( $\mathrm{L}$ and $\mathrm{S}$ forms). While analysing transport of the GFP-2b-TRV construct, Valentine et al. (2004) showed that movement of the virus to non-inoculated leaves and roots of Arabidopsis thaliana and Nicotiana benthamiana is more efficient in the presence of protein $2 b$.

Our observations indicate that in the majority of cases the non-capsidated virions of TRV took part in the intercellular transport. This confirms the theory that Tobravirus TRV belongs to a small group of viruses that do not need capsid protein for transport (Swanson et al. 2002; MacFarlane 2010).

Our ultrastructural analysis of susceptible tobacco and potato plants shows that both capsidated and non-capsidated virions, of varied length, participate in long-distance transport. TRV particles were more often documented in xylem (tracheary elements and parenchyma) than in phloem. Observations inside the sieve element showed 


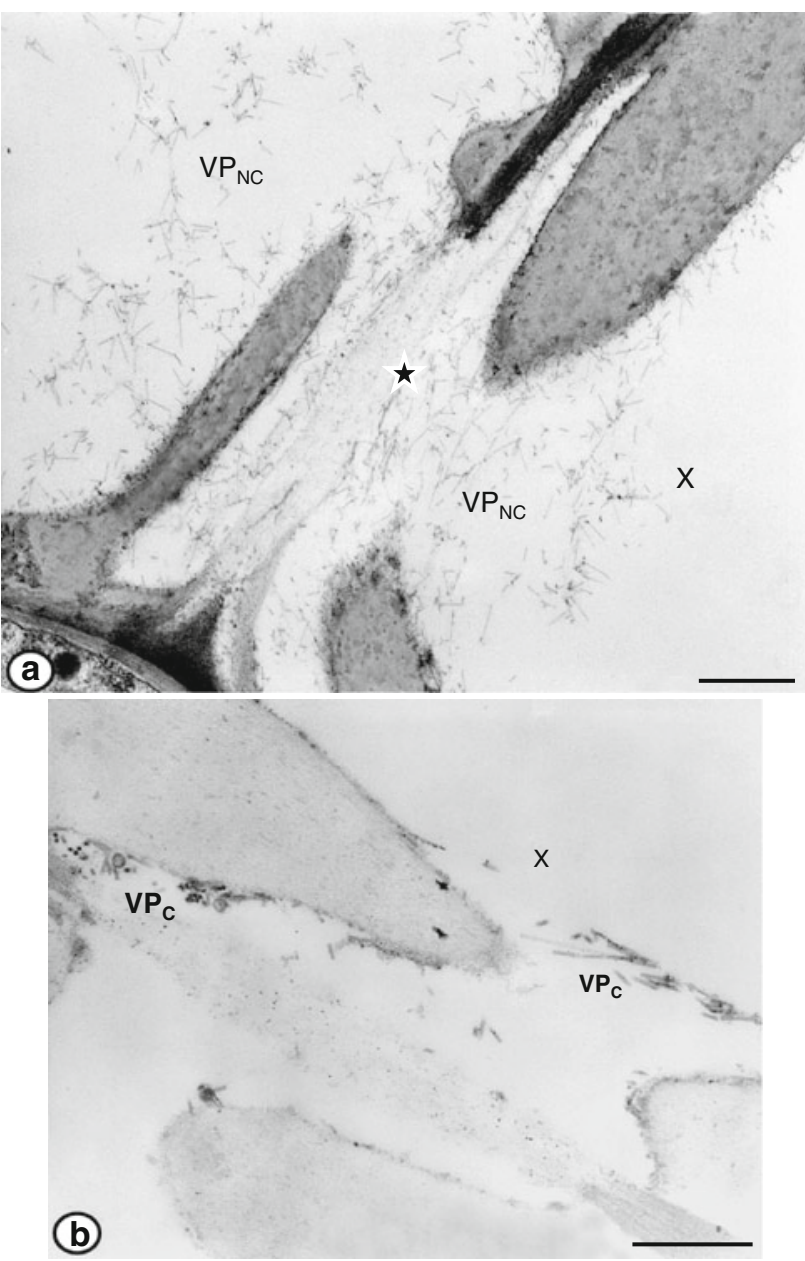

Fig. 9 TRV virions in xylem tracheary elements. a Non-capsidated TRV particles $\left(\mathrm{VP}_{\mathrm{NC}}\right)$ in dispersed form inside of xylem $(\mathrm{X})$ tracheary elements in tobacco stem. TRV particles in bordered pit (indicated by arrow). Bar $500 \mathrm{~nm}$; b capsidated TRV particles $\left(\mathrm{VP}_{\mathrm{C}}\right)$ at longitudinal section and cross section inside a xylem (X) tracheary element of tobacco root. Particles also visible within bordered pit. Bar 500 nm

only the presence of non-capsidated particles. Our data suggest that non-capsidated type virions participate more often in transport from cell to cell than within the plant vascular system. Our observations confirm the conclusions of Swanson et al. (2002) regarding the transport of infection GFP-TRV and GFP-PEBV clones. Mutated viruses without coat protein were able to move systemically in $N$. benthamiana and $N$. clevelandii plants with the same speed as a wild-type virus. Moreover, virions without coat protein could also leave the conductive tissue in systemically infected leaves. Xylem transport by plant viruses was originally proposed in the studies of Sobemoviruses such as Rice yellow mottle virus (RYMV) and Blueberry shoestring virus (Opalka et al. 1998; Urban et al. 1989). In immunogold labelling studies using light and electron microscopy, Beet necrotic yellow vein virus (BNYVV) and Soilborne
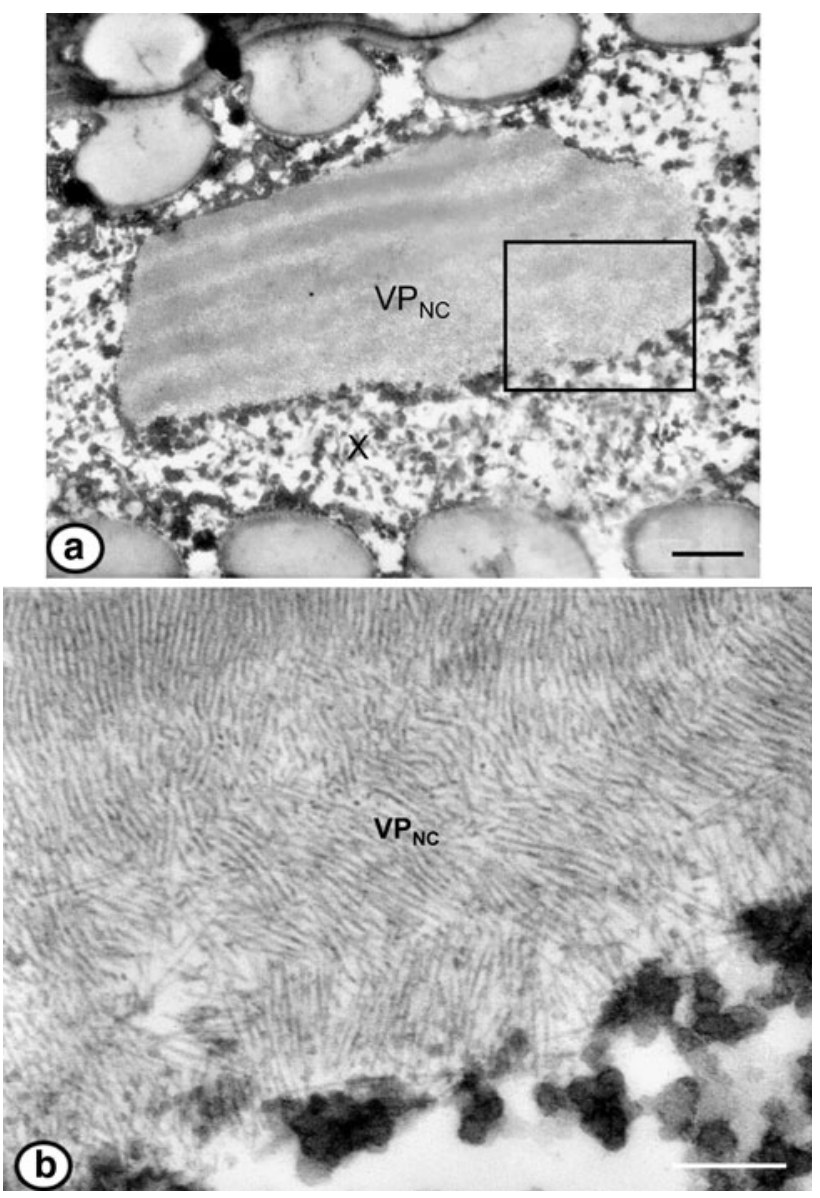

Fig. $10 \mathrm{VP}_{\mathrm{NC}}$ in the xylem tracheary elements. a Regular inclusion of non-capsidated TRV particles $\left(\mathrm{VP}_{\mathrm{NC}}\right)$ inside the xylem $(\mathrm{X})$ tracheary element. Bar $1 \mu \mathrm{m}$; b enlarged marked fragment from a. Bar $500 \mathrm{~nm}$

wheat mosaic virus (SBWMV) were each detected in xylem vessels or xylem parenchyma in infected plant roots (Dubois et al. 1994; Verchot et al. 2001). SBWMV inclusion bodies were also identified in xylem parenchyma and xylem vessels in infected wheat roots. Otulak and Garbaczewska (2010) detected Potato virus $Y$ particles and capsid proteins in xylem tracheary elements and in xylem parenchyma in infected potato leaflets. RYMV and SBWMV have been detected in immature xylem elements prior to cell death. The virus is likely to move from cell to cell into immature xylem and then undergo replication. After programmed cell death, virus particles are released into the xylem and can move upward in the plant (Verchot et al. 2001; Verchot-Lubicz 2003). There is evidence that viruses may enter immature xylem elements, which have plasmodesmata connections with parenchyma cells. Thus, virus xylem loading would be developmentally regulated. We do not yet know if xylem transport is an essential component of viral long distance movement. 
Author contribution Grażyna Garbaczewska and Marcin Chouda designed and performed experiments, Katarzyna Otulak analysed data and prepared the manuscript, Mirosława Chrzanowska conceptual advice and instructed the experiments.

Acknowledgments We thank inż. Ewa Znojek for expert technical assistance.

Conflict of interest The authors declare that they have no conflict of interests.

Open Access This article is distributed under the terms of the Creative Commons Attribution License which permits any use, distribution, and reproduction in any medium, provided the original author(s) and the source are credited.

\section{References}

Allen TC (1963) A strain of tobacco rattle virus from Oregon grown potatoes. Plant Dis Rep 47:920-923

Bergh ST, Koziel MG, Huang S-C, Thomas RA, Gilley DP, Siegel A (1985) The nucleotide sequence of tobacco rattle virus RNA2 (CAM strain). Nucleic Acids Res 13:8507-8518

Carrington JC, Kasschau KD, Mahajan SK, Schaad MC (1996) Cellto-cell and long-distance transport of viruses in plants. Plant Cell 8:1669-1681

Clark MF, Adams AN (1977) Characteristics of the microplate method of enzyme-linked immunosorbent assay for the detection of plant viruses. J Gen Virol 34:475-483

Cornelissen BJC, Linthorst HJM, Brederode FT, Bol JF (1986) Analysis of the genome structure of tobacco rattle virus strain PSG. Nucleic Acids Res 14:2157-2169

Dubois F, Sangwan RS, Sangwan-Norreel BS (1994) Spread of Beet necrotic yellow vein virus in infected seedlings and plants of sugar beet (Beta vulgaris). Protoplasma 179:72-82

Frost RR, Harrisom BD, Woods RD (1967) Apparent symbiotic interaction between particles of tobacco rattle virus. J Gen Virol $1: 57-70$

Hamilton WDO, Baulcombe DC (1989) Infectious RNA produced by in vitro transcription of a full-length tobacco rattle virus RNA-1 cDNA. J Gen Virol 70:963-968

Harrison BD, Robinson DJ (1978) The tobraviruses. Adv Virus Res 23:25-77

Holeva RC, MacFarlane SA (2006) Yeast two-hybrid study of tobacco rattle virus coat protein and $2 \mathrm{~b}$ protein interactions. Arch Virol 151:2123-2132
Huth W, Lesemann DE (1984) Natural occurrence of tobacco rattle virus in rye (Secale cereale) in the Federal Republic of Germany. Phytopathologische Zeitschrift 111:1-4

Karnovsky MJ (1965) A formaldehyde-glutaraldehyde fixative of high osmolarity for use in electron microscopy. J Cell Biol 27:137A

Lister RM, Bracker CE (1969) Defectiveness and dependence in three related strains of tobacco rattle virus. Virology 37:262-275

MacFarlane SA (1999) Molecular biology of the tobraviruses. J Gen Virol 80:2799-2807

MacFarlane SA (2010) Tobraviruses-plant pathogens and tools for biotechnology. Mol Plant Pathol 11:577-583

MacFarlane SA, Brown DJF (1995) Sequence comparison of RNA2 of nematode-transmissible and nematode-non-transmissible isolates of pea early-browning virus suggests that the gene encoding the $29 \mathrm{kDa}$ protein may be involved in nematode transmission. J Gen Virol 76:1299-1304

Opalka N, Brugidou C, Bonneau C, Nicole M, Beachy RN, Yeager M, Fauquet C (1998) Movement of Rice yellow mottle virus between xylem cells through pit membrane. Proceedings of the National Academy of Science USA 95:3323-3328

Otulak K, Garbaczewska G (2010) Ultrastructural events during hypersensitive response of potato cv. Rywal infected with necrotic strains of potato virus Y. Acta Physiologia Plantarum 32:635-644

Ploeg AT, Robinson DJ, Brown DJF (1993) RNA-2 of tobacco rattle virus encodes the determinants of transmissibility by trichodorid vector nematodes. J Gen Virol 74:1463-1466

Swanson M, Barker H, MacFarlane SA (2002) Rapid vascular movement of tobraviruses does not require coat protein: evidence from mutated and wild-type viruses. Ann Appl Biol 141:259-266

Urban LA, Ramsdell DC, Klomparens KL, Lynch T, Hancock JF (1989) Detection of Blueberry shoestring virus in xylem and phloem tissues of high bush blueberry. Phytopathology 79:488493

Valentine T, Shaw J, Block VC, Philipps MS, Oparka KJ, Lacomme C (2004) Efficient virus-induced gene silencing in roots using a modified tobacco rattle virus vector. Plant Physiol 136:3999_ 4009

Verchot J, Driskel BA, Zhu Y, Hunger RM, Littlefield LJ (2001) Evidence that soilborne wheat mosaic virus moves long distance through the xylem in wheat. Protoplasma 218:57-66

Verchot-Lubicz J (2003) Soilborne viruses: advances in virus movement, virus induced gene silencing, and engineered resistance. Physiol Mol Plant Pathol 62:55-63

Ziegler-Graff V, Guilford PJ, Baulcombe DC (1991) Tobacco rattle virus RNA-1 $29 \mathrm{~K}$ gene product potentiates viral movement and also affects symptom induction in tobacco. Virology 182:145-155 